\title{
The Influence of Individual Characteristics and Transformational Leadership Style on Job Satisfaction and Employee Performance at Bank Aceh Sharia
}

\author{
Marbawi Adamy \\ Doctoral Programe School of Economic and Business \\ Universitas Sumatera Utara \\ Lecturer in University of Malikussaleh \\ Medan, Indonesia \\ marbawi.unimal@gmail.com \\ Prihatin Lumbanraja \\ Faculty of Economics and Business \\ Universitas Sumatera Utara \\ Medan, Indonesia
}

\author{
Arlina Nurbaity Lubis \\ Faculty of Economics and Business \\ Universitas Sumatera Utara \\ Medan, Indonesia \\ Elisabeth Siahaan \\ Faculty of Economics and Business \\ Universitas Sumatera Utara \\ Medan, Indonesia
}

\begin{abstract}
The purpose of this quantitative descriptive explanatory surve study was to analyze the influence individual characteristics, transformational leaders, and job satisfaction on performance of employees on PT. Bank Aceh Sharia Lhokseumawe. The research was conducted at the Bank Aceh Sharia employees located at Lhoseumawe City. The population in this research are all members of the employees at the Bank Aceh Sharia Lhokseumawe 146 employees, the samples of this researc 146 employees at Bank Aceh Sharia Lhokseumawe. The tool of analysis was SEM (Structural equation modeling) using Amos, the method of data analysis with measurmen model analysis and structure model analysis. The test results showed that simultaneous that the individual characteristic and transformational leaders effect on the job satisfaction and then individual characteristic, transformational leaders, job satisfaction effect on performance of employees on Bank Aceh Sharia Lhokseumawe, otherwise transformational leaders dominat effect on job satisfaction of employees on Bank Aceh Sharia Lhokseumawe.
\end{abstract}

Keywords-Individual Characteristics, Transformational Leaders, Job Satisfaction and Employee Performance

\section{INTRODUCTION}

The success of Bank Aceh Sharia performance lies on empowering human recources, Bank Aceh is a commercial bank owned by the government of Province, regency/city, Bank of Aceh is the Regional Development Bank committed to streng then it self to be the leading bank in the region with the business activities to collect funds, giving credit to the publicand give financial services. Now, Bank Aceh as a financial intermediary also serves as the agent of trust, as an agent of economic development,as well as community service agencieswhich participate in the context of economic development of the Acehnese.

Bank Aceh through competitive services with extensive network as well as a professionally managed improves regional economic growth that is expected to become a leading bank in Aceh. Regional Champion Bank will continue for the transformation of BPD through out Indonesia to become a champion in his own area, so the Bank of Aceh can be a Leading Regional Bank in Aceh. To support the achievement of the transformation goals BPD as Regional Champion, the bank is based on three pillars, strong resilience, the ability as Agent of Regional Development and ability to serve the needs of the community.

In 2016, Bank Aceh has been over conversion to islamic financial institution is Bank Aceh effort to welcome community's need in financial activity consistently with the norms of sharia. Starting step to Sharia institution Bank Aceh coherently follows financial institutions principles based on islamic law derived from the Quran and Hadist. Through management principle of sharia banking, Bank Aceh competes and maintains its image as an attempt to streng then the bonds of trust of our customers and partners and then transform complete to Bank Aceh Sharia [1].

\section{BASIC THEORY AND HYPOTHESES DEVELOPMENT}

\section{A. Performance}

Bernadin \& Russell [2] provides limitations on the performance as a "record of out come produced on a specified job function or activity during, a specified time period". Then, the appraisal of performance is" away of measuring the contributions of individuals to their organization". Bernadin \& 
Russell (1998) proposed six criteria for measuring the performance of employees, namely:

1. Quality :The degree to which the process or result of carrying out activity approaches, in term of either conforming to some ideal way of performing the activity or fulfilling the activity's intended purpose.

2. Quantity :The amount produces, expressed in such terms as dollar value, number of unit, or number of completed activity cycles.

3. Timeliness : The degree to which an activity is completed, or a result produced, at the earliest time desirable from the standpoints of both coordinating with the outputs of others and maximizing the time available for other activities.

4. Cost-Effectiveness : The degree to which the use of the organization's resources (e.g., human, monetary, technological, material) is maximized in the sense of getting the highest gain or reduction in loss from each unit or instance of the use of a resource.

5. Need for Supervision: The degree to which a performar can carry out a job function without either having to request supervisory assistance or requiring supervisory intervention to prevent an adverse outcome.

6. Interpersonal Impact: The degree to which a performer promotes feelings of self-esteem, goodwill, and cooperativeness among coworkers and subordinates.

\section{B. Job Satisfaction}

Luthans [3], says"a comprehensive definition ofjob satisfaction as involving cognitive, affective, and evaluative reactions or attitudes and state it is "a pleasurable or positive emotional state the resulting from the appraisal of one 's job or job experience". Job satisfaction is a result of the employees' perception of how well their job provides those things that are viewed as important. The factors that determine job satisfaction according to Luthans [3], in Siahaan [4], namely:

1. The work it self;

2. Payroll system;

3. Promotion opportunities;

4. Supervision;

5. Coworkers;

6. Work Condition;

In this study the indicators used to measure employee satisfaction at the Bank Aceh Sharia using indicators that have been done in Siahaan [4], namely nature of the work, coworkers, supervision characteristics, payroll and opportunities for promotion.

\section{Individual Characteristics}

Rivai [5] states that "the individual characteristics are special characteristics, the properties of psychological, moral or character of a person who distinguishes with other people". The most important resource in the organization is the human resource, the people who give you energy, talent, creativity, and their efforts to the organization for an organization to keep its existence. Every human being has individual characteristics that are different from one another. Mathiue \& Zajac [6] state that personal characteristics include age, gender, education level, ethnicity, and personality. Robbins [7] states that the factors which is easily defined and available, data that can be obtained most of the information provided in the personnel file of an employee expressed in the individual characteristics include age, gender, marital status, number of dependents and tenure in the organization. Siagian [8] states that, biographical characteristics can be seen on the age, sex, marital status, number of dependents and the work period. Based on several expert opinions about the instruments to measure variables individual characteristics, so in this study the author uses and adopts dimensions of the individual characteristics of the study conducted by Lumbanraja [9], namely: the individual characteristics can be influenced by physical factors consisting of the shape of the body, the level of physical health, and the ability of the senses while the differences in psychological factors include: intelligence, talent, personality and level of education. However, in the study of individual characteristic variables, it measures the dimensions of the ability, attitudes, values, personality and learning.

\section{Transformational Leadership}

Leadership style is developed in the context of the organization, where transformational leadership caresto the improved performance, and develops followers to the maximum potential Avolio, [14]; Bass \& Avolio, [10] in Northouse [13]. Burns [11] suggested that transformational leadership is a process in which leaders and subordinates lift each other to the degree of morality and motivation higher."Leadersand followers raise one another to higher levels of morality andmotivation", where leaders are trying to change thefollowers' consciousness on ideals and moral values such as equality, justice, peace, as well as humanitarian and instead is based emotions, such as fear, jealousy, or hatred. In Roobins \& Judge [7] Transformational Leaders inspire followers to transcend reviews their self-interest for the good of the organization and can have an extraordinary effect on their followers. In this study, the dimensional measure of transformational leadership is charisma and influence, inspirational motivation, intellectual stimulation and individual attention

According to Sekaran [15] the hypothesis is defined as a relationship that is expected to logically between two or more variables are expressed in the form of a statement that can be tested, the relationship is estimated based network of associations that can be tested. This research is based on the formulation of the problem, the theoretical basis and previous studies, the hypothesis can be formulated as follows:

1. There is the influence of individual characteristics on job satisfaction at Bank Aceh Sharia Lhokseumawe.

2. There is the influence of transformational leadership on on job satisfaction at Bank Aceh Sharia Lhokseumawe.

3. There is the influence of individual characteristics on employee performance at Bank Aceh Sharia Lhokseumawe.

4. There is the influence of transformational leadership on employee performance at Bank Aceh Sharia Lhokseumawe.

5. There is the influence of job satisfaction oo employees performance at Bank Aceh Sharia Lhokseumawe. 
Conceptual Framework

Based on several previous studies which have been investigated by researchers previously against some of the variables that are related to this research, and also refers to some theories that have been presented by experts, it can be described the conceptual framework as follows: Figure 1.

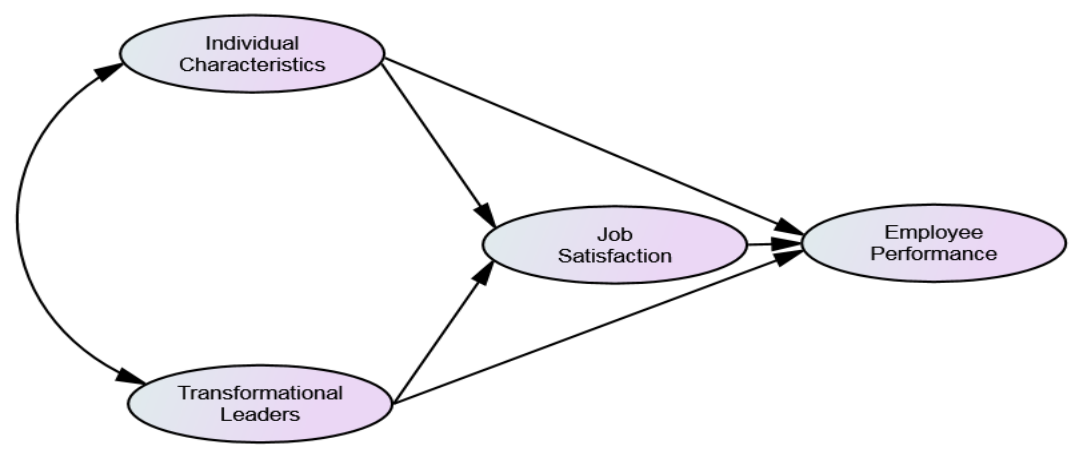

Figure 1. Conceptual Model

\section{METHODOLOGY}

\section{A. Location And Time}

The subjects in this study were employees of Bank Aceh Sharia Lhokseumawe, which all employees who were at the bank branch in Bank Aceh Sharia Lhokseumawe, the location was done in Bank Aceh Sharia Lhokseumawe at Merdeka St. No. 8, Lhokseumawe and Bank Aceh Sharia Lhokseumawe the location at Samudra St. No. 29, Desa Lancang Garam, Lhokseumawe.

\section{B. Types And Sources of Data}

The type of data in this research is quantitative data. The data used in this study are primary data from the respondents' perception of the variables used. Any form of communication with the respondents in this study used questionnaires submitted directly to the respondent.

\section{Population}

Populationis a combination of all the elements that have a series of similar characteristics which include the benefit of the research problem. Target population in Bank Aceh Sharia Lhokseumawe were 146 employees, who are on a bank branch in Lhokseumawe, with a total population of 146 people.

\section{Samples}

The amount of samples taken at branch of Bank Aceh Sharia Lhokseumawe by total population, based on the total population of employees at each branch of the Bank Aceh Sharia Lhokseumawe. In this study the number of samples is 146 respondents based on the condition of SEM at maximun likelihood estimation (ML) is 100-200 sample, in [16].

\section{E. Data Collection Techniques}

Data collection method used in this research is by using questionnaire instrument, which is a set of written questions to elicit information from respondents. In this study a questionnaire sheet, there are two types of statements / questions: (1) statements relating to the measurement of the variables; (2) questions relating to the respondent data. Questionnaire is made of the statements / structured questions and provides an answer in the form of scale with answers that are tailored to the statements / questions to make respondentseasier to answer and avoid bias. The measurement used isLikert scale where each statement has answers are 1 (strongly disagree), 2 (disagree), 3 (neutral), 4 (agree) to 5 (strongly agree).

\section{F. Data Analysis Techniques}

Inferential statistic isa method related to sample analysis to draw conclusions about the characteristics of the population. After collecting the data and information in the field, then to manage data and information, the writer used the Structural Equation Model (SEM) in the model and hypothesis testing. This study used two kinds of analysis techniques, with the Amos program based on measurement model and structural model [17] :

1. Measurement model has indicators reflecting evaluated by convergen validity of significant $\mathrm{P}$ value $<0,05$ and indicator loading factor $>0,50$ and ideal $>0,70$ and contruct reliability minimum 0,70 and cut of value variance extracted minimum 0,50 with to qualify the structural equation modeling (SEM).

2. Structural model is evaluated by using comparison of goodness-of-fit measures for laten constructs, a complete SEM analysis involves both the tes of a measuremen theory and the structural theory that link construcs together in a logically meaningful way.

\section{RESULTS AND DISCUSSION}

\section{A. Measurement Model Analysis Results}

Convergent validity part of the measurement model within SEM and is usually referred to as measurement model while the covariance-based SEM-called confirmatory factor analysis (CFA) in Ferdinand, [16]. There are two criteria to assess 
whether the measurement model is eligible to construct reflective convergent validity, namely (1) loading factor should be above mimimim $>0,50$ or ideal $>0.70$ and (2) $\mathrm{P}_{\text {value }} \mathrm{a}$ significant $<0.05$ in the study of these requirements have all been fulfilled, [17]. Then to test validity Contruct can be seen at confirmatory factor analysis (CFA) in Figure 2 and Table 1 below are as follows:

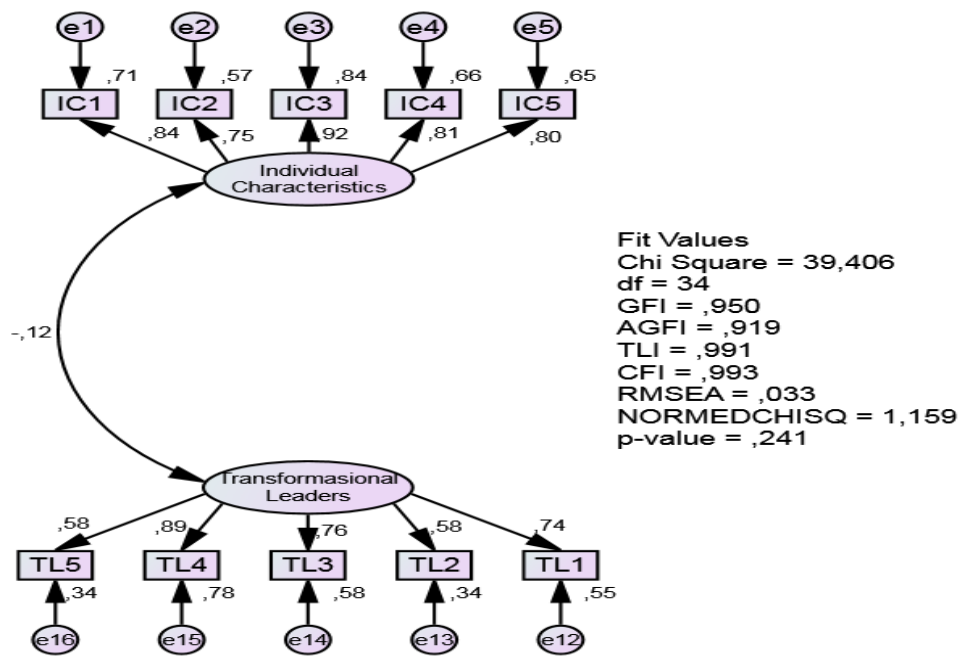

Figure 2. Confirmatory Factor Analysis Exogen Contruct

Table 1: Loading Estimates of Exsogen Contruct

\begin{tabular}{cclccc}
\hline & & Indicator & $\begin{array}{c}\text { Loading } \\
\text { Factor }\end{array}$ & Cut Off Value & Results \\
\hline IC1 & $<---$ & Individual Characteristics & 0,840 & $\geq 0,50$ & Valid \\
IC2 & $<---$ & Individual Characteristics & 0,752 & $\geq 0,50$ & Valid \\
IC3 & $<---$ & Individual Characteristics & 0,915 & $\geq 0,50$ & Valid \\
IC4 & $<---$ & Individual Characteristics & 0,813 & $\geq 0,50$ & Valid \\
IC5 & $<---$ & Individual Characteristics & 0,804 & $\geq 0,50$ & Valid \\
TL1 & $<---$ & Transformasional Leaders & 0,745 & $\geq 0,50$ & Valid \\
TL2 & $<---$ & Transformasional Leaders & 0,580 & $\geq 0,50$ & Valid \\
TL3 & $<---$ & Transformasional Leaders & 0,759 & $\geq 0,50$ & Valid \\
TL4 & $<---$ & Transformasional Leaders & 0,885 & $\geq 0,50$ & Valid \\
TL5 & $<---$ & Transformasional Leaders & 0,582 & $\geq 0,50$ & Valid \\
\hline
\end{tabular}

Source : Amos Analysis 2017

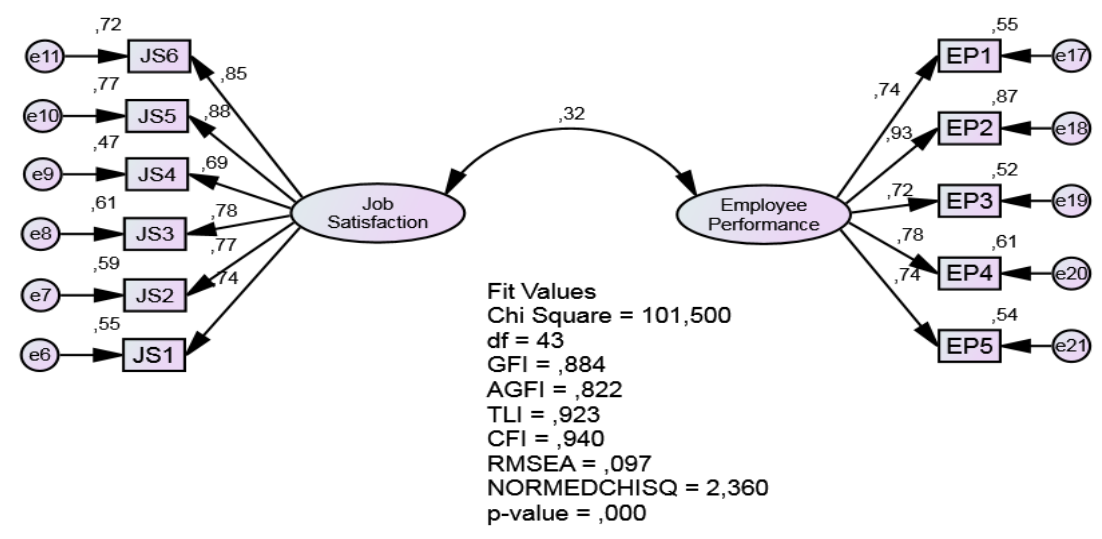

Figure 3. Confirmatory Factor Analysis Endogen Contruct 
Table 2: Loading Estimates of Edogen Contruct

\begin{tabular}{lccccc}
\hline & & Indicator & $\begin{array}{c}\text { Loading } \\
\text { Factor }\end{array}$ & Cut Off Value & Results \\
\hline JS1 & $<---$ & Job Satisfaction & 0,738 & $\geq 0,50$ & Valid \\
JS2 & $<---$ & Job Satisfaction & 0,771 & $\geq 0,50$ & Valid \\
JS3 & $<---$ & Job Satisfaction & 0,781 & $\geq 0,50$ & Valid \\
JS4 & $<---$ & Job Satisfaction & 0,686 & $\geq 0,50$ & Valid \\
JS5 & $<---$ & Job Satisfaction & 0,880 & $\geq 0,50$ & Valid \\
JS6 & $<---$ & Job Satisfaction & 0,848 & $\geq 0,50$ & Valid \\
EP1 & $<--$ & Employee Performance & 0,742 & $\geq 0,50$ & Valid \\
EP2 & $<---$ & Employee Performance & 0,932 & $\geq 0,50$ & Valid \\
EP3 & $<---$ & Employee Performance & 0,723 & $\geq 0,50$ & Valid \\
EP4 & $<---$ & Employee Performance & 0,782 & $\geq 0,50$ & Valid \\
EP5 & $<---$ & Employee Performance & 0,738 & $\geq 0,50$ & Valid \\
\hline
\end{tabular}

Source : Amos Analysis 2017

Based on testing confirmatory factor analysis, the value of loading factor estimates suggested is above 0.50 and convergent validity significan $<0,05$ then the results of the analysis of reliability evaluation by contruct reliability $(\mathrm{CR})>0,70$ the value of Variance Extracted (AVE) suggested is above 0.50 based on Table 2 above [16].

B. Structural Model Analysis Results
The analysis results of structural equation modelling are presented in the table and the picture as follows as shown in Figure 4 and Table 3 :

Based on figure 5 and Table 4 Goodness of Fit Indexs Full Model, it is found out that the whole parameters have already met the thereshold requirements, so that the model is feasible to be used for hypothetical testing.

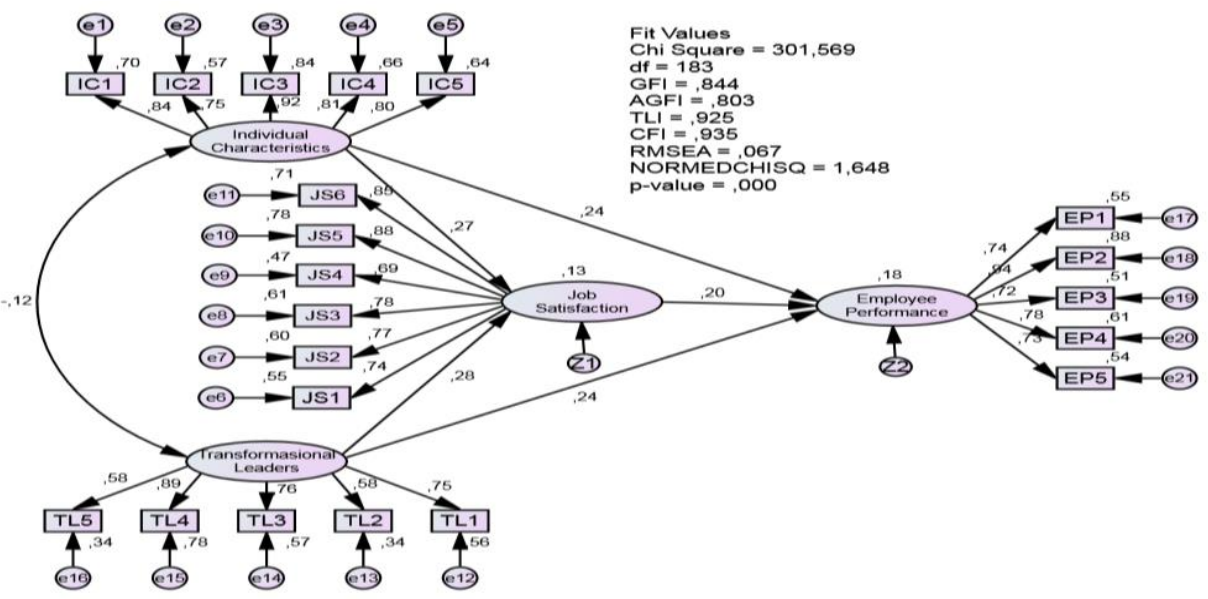

Figure 4. Outputs Sructural Model Before Modification 
Table 3: Goodness of Fit Indexs Full Model Before Modification Indicies

\begin{tabular}{cccc}
\hline Goodness of Fit Index & Cut-off Value & Result Analisysis & Model Evaluation \\
\hline$\chi^{2}$ Chi-Square Statistik & Diharapkan Kecil & 301,569 & Marginal \\
Probability & $\geq 0,05$ & 0.000 & Good \\
CMIN/DF & $\leq 2.00$ & 1.648 & Good \\
GFI & $\geq 0.90$ & 0.844 & Marginal \\
AGFI & $\geq 0.90$ & 0,803 & Marginal \\
TLI & $\geq 0.95$ & 0.925 & Good \\
CFI & $\geq 0.95$ & 0.935 & Good \\
RMSEA & $\leq 0.08$ & 0,067 & Good \\
\hline
\end{tabular}

Source : Amos Analysis 2017

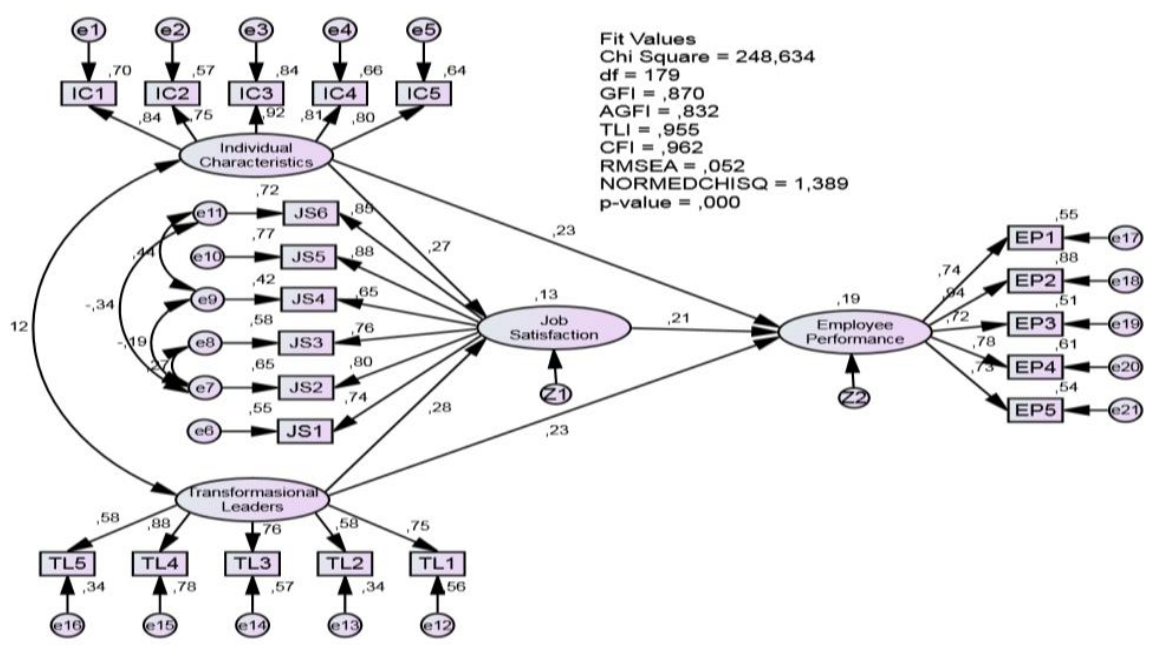

Figure 5. Outputs of Sructural Equation Model After Modification

Table 4: Goodness of Fit Indexs Full Model After Modification Indicies

\begin{tabular}{cccc}
\hline Goodness of Fit Index & Cut-off Value & Result Analisysis & Model Evaluation \\
\hline$\chi^{2}$ Chi-Square Statistik & Diharapkan Kecil & 248,634 & Good \\
Probability & $\geq 0,05$ & 0.000 & Good \\
CMIN/DF & $\leq 2.00$ & 1.389 & Good \\
GFI & $\geq 0.90$ & 0.870 & Marginal \\
AGFI & $\geq 0.90$ & 0,832 & Marginal \\
TLI & $\geq 0.95$ & 0.955 & Good \\
CFI & $\geq 0.95$ & 0.962 & Good \\
RMSEA & $\leq 0.08$ & 0,052 & Good \\
\hline
\end{tabular}

Source : Amos Analysis 2017

Table 5 : Standardized Direct, Indirect \& Total Effects

\begin{tabular}{ccccc}
\hline Variavel & $\begin{array}{c}\text { Transformational } \\
\text { Leaders }\end{array}$ & $\begin{array}{c}\text { Individual } \\
\text { Characteristic }\end{array}$ & $\begin{array}{c}\text { Job } \\
\text { Satisfaction }\end{array}$ & $\begin{array}{c}\text { Employee } \\
\text { Performance }\end{array}$ \\
\hline Direct Effects & 0.278 & 0.271 & 0.000 & 0,000 \\
Job Satisfaction & 0.234 & 0.233 & 0.212 & 0,000 \\
Employee Performance & & & & \\
Indirect Effects & 0,000 & 0,000 & 0,000 & 0,000 \\
Job Satisfaction & 0.059 & 0.057 & 0.000 & 0.000 \\
Employee Performance & & & & \\
Total Effects & 0.278 & 0.271 & 0.000 & 0,000 \\
Job Satisfaction & 0.293 & 0.290 & 0.212 & 0,000 \\
Employee Performance & & & &
\end{tabular}


Table 6 : Outputs of Hypothetical Testing

\begin{tabular}{llcccc}
\multicolumn{1}{c}{ Vyp } & \multicolumn{1}{c}{ Variabel } & Coefficient & CR & P & Remarks \\
\hline $\mathrm{H}_{1}$ & Individual Characteristics $\left(\mathrm{X}_{1}\right)$ to the Job Satisfaction $\left(\mathrm{Y}_{1}\right)$ & 0.271 & 3.053 & 0.002 & Significant \\
$\mathrm{H}_{2}$ & Transformational Leaders $\left(\mathrm{X}_{2}\right)$ to the Job Satisfaction $\left(\mathrm{Y}_{1}\right)$ & 0.278 & 3,027 & 0.002 & Significant \\
$\mathrm{H}_{3}$ & Individual Characteristics $\left(\mathrm{X}_{1}\right)$ to the Employee Performance $\left(\mathrm{Y}_{2}\right)$ & 0.233 & 2.567 & 0.010 & Significant \\
$\mathrm{H}_{4}$ & Transformational Leaders $\left(\mathrm{X}_{2}\right)$ to the Employee Performance & 0.234 & 2.514 & 0.012 & Significant \\
& $\left(\mathrm{Y}_{2}\right)$ & 0.212 & 2.287 & 0.022 & Significant \\
$\mathrm{H}_{5}$ & Job Satisfaction $\left(\mathrm{Y}_{1}\right)$ to the Employee Performance $\left(\mathrm{Y}_{2}\right)$ & &
\end{tabular}

Source : Amos Analysis 2017

\section{Discussion}

$\mathrm{H}_{1}$ There is a positive and significant effect of the individual characteristics on job satisfaction at Bank Aceh Sharia Lhokseumawe.

Based on Table 6 , the known value of $P$-value between individual characteristics on job satisfaction was 0.002 , which is smaller than the significance level of 0.05 . These results can be concluded that the individual characteristic variable significantly influences the job satisfaction of the Bank Aceh Sharia Lhokseumawe. Based on the results of path coefficient value of the individual characteristics on job satisfaction is 0.274 positive coefficient path meaning the individual characteristics on job satisfaction has a positive effect on the Bank Aceh Sharia. Hypothesis 1 in this research is the influence of individual characteristic on job satisfaction on Bank Aceh Sharia Lhokseumawe accepted. Worth mentioning that the research results are consistent with studies conducted [9], the research results show that the individual characteristic has effect on the job satisfaction.

$\mathrm{H}_{2}$ There is a positive and significant effect of transformational leadership on job satisfaction at Bank Aceh Sharia Lhokseumawe.

Based on Table 6, the known value of $P$-value between transformational leadership on job satisfaction was 0.002 , which is smaller than the significance level of 0.05 . These results can be concluded that the transformational leadership variable significantly influences the job satisfaction of the Bank Aceh Sharia Lhokseumawe. Based on the results of path coefficient value of the transformational leadership on job satisfaction is 3,027 positive coefficient path meaning the transformational leadership on job satisfaction has a positive effect on the Bank Aceh Sayaria. Hypothesis 2 in this research is the influence of transformational leadership on job satisfaction on Bank Aceh Sharia Lhokseumaweis accepted. Worth mentioning that the research results are consistent with studies conducted [9], the research results show that the transformational leadership has effect on the job satisfaction.

$\mathrm{H}_{3}$ There is a positive and significant influence of individual characteristics on employee performance at Bank Aceh Sharia Lhokseumawe.

Based on Table 6, the known value of $P$-value between individual characteristics on employee performance was 0.010 , which is smaller than the significance level of 0.05 . These results can be concluded that the individual characteristics variable significantly influences the employee performance of the Bank Aceh Sharia Lhokseumawe. Based on the results of path coefficient value of the individual characteristics on employee performance is 0,192 positive coefficient path meaning the individual characteristics on employee performance has a positive effect on the Bank Aceh Sayaria. Hypothesis 3 in this research is the influence of individual characteristics on employee performance on Bank Aceh Sharia Lhokseumawe accepted. The result supports the research with studies [18], [19], the research results show that the individual characteristics effect on the employee performance.

$\mathrm{H}_{4}$ There is a positive and significant impact of transformational leadership on employee performance at Bank Aceh Sharia Lhokseumawe.

Based on Table 6 , the known value of $P$-value between transformasional leadership on employee performance was 0.012 , which is smaller than the significance level of 0.05 . These results can be concluded that the transformational leadres variable significantly influences the employee performance of the Bank Aceh Sharia Lhokseumawe. Based on the results of path coefficient value of the transformational leadres on employee performance is 0,243 positive coefficient path meaning the transformational leaders on employee performance has a positive effect on the Bank Aceh Sharia. Hypothesis 4 in this research is the influence of transformational leaders on employee performance on Bank Aceh Sharia Lhokseumawe accepted. The result supports the research with studies [4], [20], [10], the research results show that the transformational leaders effects on the employee performance.

$\mathrm{H}_{5}$ There is a positive and significant influence of job satisfaction on employees performance at at Bank Aceh Sharia Lhokseumawe.

Based on Table 6, the known value of $P$-value between job satisfaction on employee performance was 0.022 , which is smaller than the significance level of 0.05 . These results can be concluded that the job satisfaction variable significantly influences the employee performance of the Bank Aceh Sharia Lhokseumawe. Based on the results of path coefficient value of the job satisfaction on employee performance is 0,243 positive coefficient path meaning the job satisfaction on employee performance has a positive effect on the Bank Aceh Saria. Hypothesis 5 in this research is the influence of job satisfaction on employee performance on Bank Aceh Sharia Lhokseumawe 
accepted. The result supports the research with studies [4], [21], [10], [22], \& [7], the research results show that the job satisfaction effects on the employee performance.

\section{Conclusion}

1. The result of the first hypothesis testing showed that the influence of individual characteristics on job satisfaction at the Bank Aceh Sharia Lhokseumawe.

2. The result of $2^{\text {nd }}$ hypothesis testing showed the influence of transformational leadership on job satisfaction at the Bank Aceh Sharia Lhokseumawe.

3. The result of $3^{\text {rd }}$ hypothesis testing showed individual characteristics of influence employee performance at the Bank Aceh Sharia Lhokseumawe.

4. The result of $4^{\text {th }}$ hypothesis testing showed that the influence of transformational leadership on employee performance at the Bank Aceh Sharia Lhokseumawe.

5. The result of $5^{\text {th }}$ hypothesis testing showed that the job satisfaction on employee performance Bank Aceh Sharia Lhokseumawe.

\section{SUGGESTIONS}

1. The contruct of individual characteristics and transformational leadership influence on job satisfaction of employees at the Bank Aceh Sharia Lhokseumawe, it needs the attention of Bank Aceh Sharia management to continue improving the individual characteristics and leadership behaviors in order employee satisfaction to continue rising as well.

2. The contruct of transformational leadership dominand affect to employee performance at the Bank Aceh Sharia Lhokseumawe, it also needs the attention of the management of Bank Aceh Sharia to continue maintaining and improving the behavior of its leadership, employee characteristics and transformational leaders so that employees feel close and got the attention of management, and maintain the value cultural values that had been occupied, it will have an impact on employee performance improvement at the Bank Aceh Sharia Lhokseumawe.

\section{References}

[1] Annual Report. Bank Aceh Syaria, 2015..

[2] Bernadin, H. John and Joyce. A. Russell. Human Resource Management: An Experiential Approach, Boston : Mc.Graw Hill, 1993.

[3] Luthans, Fred. Organizational Behavior, Tweltf Edition, McGrawHill Companies Inc. New York. 2011.
[4] Siahaan, Elisabet. The Antecedent of employee's performance and its influence toward employee's job satisfaction (A studi based on gender perspective at Banking Service sector in DKI Jakarta Region. Universitas Brawijaya Program Pascasarjana, Malang. 2007.

[5] Rivai, Veithzal dan E.J. Sagala., Human resource management for Businees: dari Teori Ke Praktik, Edisi Pertama, Penerbit PT. Raja Grafindo Persada, Jakarta. 2011.

[6] Mathiu, J.E., \& Zajac, D.M. A. review and meta-analysis of the antecedents, correlates and consequaences of organizational commitment. Pyschological Bulleting, 108, 171-194. 1990.

[7] Robbins, Stephen P dan Timothy A. Judge., Organizational Behavior, Prentice Hall Inc., New Jersey. 2013.

[8] Siagian. P. Sondang., Human Resource Management. Penerbit Bumi Aksara, Jakrta. 2008.

[9] Lumbanraja, Prihatin. Desertation : The influence of individual characteristic, leadership style and organization culture toward work satisfaction and organization commitment - studi at local Goverment in North Sumatera Provice. Program Pascasarjana, Universitas Brawijaya Malang. 2007.

[10] Bass, B.M., "From Transactional to transformational leadership : Learning to share the vision" Organizational Dynamics, 18, 19-31. 1990.

[11] Burns, J. M., Leadership. Happer \& Row. 1978.

[12] House, R.J., A Path-Goal Theory of Leader Effectiviness. AdministrativeScience Quarterly, 16, 321-338. 1997.

[13] Northouse, Peter. G. Leadership, Teori dan Praktik, Edisi Keenam, Penerbit PT. Indeks, Jakarta. 2013.

[14] Avolio, B.J., \& Bass, B.M. "Improving Organizationaol effectivenes through transfomational leadership". Thousand Oaks, CA: Sage. 1994.

[15] Sekaran, Uma., Research Methods For Busines, penerbit Salemba empat, Jakarta. 2007.

[16] Ferdinand, Augusty. Research Methods For Managent, Edisi kelima BPUNDIP, Semarang. 2014

[17] Hair, J.F. et al., Multivariate Data Analysis. Seventh Edition, New Jersey. Prentice-Hall. 2010.

[18] Yakin, Didik Chusnul at.all Effect of implementation of policies, individual caharacteristic, organization characteristics on work motivation and Performance at the village Secretary Mojokorto, Administration Journal Public Vol 11. Hal.129-145. 2013.

[19] Djamaluddin, Musa Effect of influence organization commitmen, carreer depelovement, workmotivation and individual characteristic to job satisfaction and employee performance east Halmahera Regency. Jurnal Analis Manajemen Vol 5, No.2. 2009

[20] Ogbonna, Emmanuel and Harris Llyod. C,. Leadership Style. Organizational Culture and Perfomance : Empirical Evidence from UK Companies, Journal of Human Resources Management 11:4. 2000.

[21] Brasmasari, Ida Ayu dan Suprayetno, Agus., The influence of work motivation and organization culture, toward work satisfaction and performance. Studi kasus pada PT. Pei Hai International Witama Indonesia. Jurnal, Manajemen dan Kewirausahaan, Vol. 10. Nomor. 2, 2008

[22] Koesmono H. Teman. The influence of organization culture toward motivation and job satisfaction and employee performance Pada Sub Sektor Industri Pengelahan Kayu Ekspor di Jawa Timur, Desertasi Universitas Airlangga, Surabaya. 2005. 